\title{
POCZUCIE NIESPRAWNOŚCI CHORYCH NA SZPICZAKA MNOGIEGO LECZONYCH W ODDZIALE HEMATOLOGICZNYM
}

\section{THE SENSE OF DISABILITY IN PATIENTS WITH MULTIPLE MYELOMA TREATED AT THE HEMATOLOGY WARD}

\author{
Karolina Chabior, Patrycja Zurzycka, Iwona Repka, Grażyna Puto \\ Zakład Pielęgniarstwa Klinicznego, Instytut Pielęgniarstwa i Położnictwa, Uniwersytet Jagielloński, Collegium Medicum
}

DOl: https://doi.org/10.20883/ppnoz.2019.31

\begin{abstract}
STRESZCZENIE
Wstęp. Szpiczak mnogi jest przewlekłą chorobą nowotworową układu hematologicznego człowieka wywodzącą się z nieprawidłowości rozrostu monoklonalnych komórek powstałych w szpiku kostnym. Powoduje często niesprawność chorych i skrócenie czasu ich życia. Osoba taka wymaga leczenia specjalistycznego oraz interdyscyplinarnej opieki.

Cel. Celem pracy było poznanie odczuć pacjentów co do własnej sprawności fizycznej w przebiegu choroby przewlekłej, jaką jest szpiczak mnogi.

Materiał i metody. Do badania poczucia niesprawności badanych pacjentów posłużyła ankieta oparta na standaryzowanych kwestionariuszach EORTC QLQ-30 + QLQ-MY-20 oraz skala akceptacji choroby AIS. Informacje zostały zebrane metodą sondażu diagnostycznego wśród pacjentów oddziałów hematologii.

Wyniki. Ponad 3/4 chorych cierpi na dolegliwości bólowe o różnym stopniu nasilenia, które przeszkadzają w wykonywaniu codziennych czynności. W skali AIS tylko 29\% pacjentów osiągnęło wynik bardzo dobrego przystosowania do choroby.

Wnioski. Szpiczak mnogi przyczynia się do zaburzenia przede wszystkim sfery fizycznej, ale także psychologicznej i socjalnej chorego.

Słowa kluczowe: szpiczak mnogi, niesprawność, ból.

ABSTRACT

Introduction. Multiple myeloma is a chronic disease of human haematological tumor derived from a monoclonal cell proliferation irregularities arising in the bone marrow. Often causes malfunction of patients and shorten their lives. Such a person requires specialist treatment and interdisciplinary care. Aim. The aim of this study was to investigate the patients feel about their physical fitness in the course of chronic disease, which is multiple myeloma.

Material and methods. A sense of disability of the patients served survey based on a standardized questionnaire EORTC QLQ-30 + QLQ-MY-20 and the scale of acceptance disease AIS. The information collected by diagnostic survey, were among the patients of the hematology wards.

Results. More than $3 / 4$ of the patients suffer from pain of varying degrees of severity, which interferes with their daily activities. On AIS scale only $29 \%$ of patients achieved very good adaptation to disease.

Conclusions. Multiple myeloma contributes to the disorder primarily the physical realm, but also psychological and social ill.
\end{abstract}

Keywords: multiple myeloma, disability, pain.

\section{Wstęp}

Szpiczak mnogi (ang. multiple myleoma - MM), nazywany również plazmocytowym (ang. plasma cells myleoma - PCM), jest nowotworem układu hematologicznego, charakteryzującym się rozrostem i akumulacją monoklonalnych komórek plazmatycznych w szpiku kostnym. W schorzeniu tym występują typowe uszkodzenia wielu narządów i układów ciała człowieka (m.in. zaburzenia produkcji szpiku kostnego, pracy nerek, serca, układu odpornościowego i nerwowego), wtórne do nieprawidłowego procesu tworzenia się komórek szpiczakowych. Rozwój nowotworu plazmocytowego przebiega wieloetapowo, od przejścia ze stadium bezobjawowego, poprzez pełnoobjawowy zespół szpiczaka mnogiego, aż do końcowej fazy białaczki plazmocytowej [1]. W skali globalnej choro- ba ta dotyka 0,4-5/100 000 indywidualnych przypadków w ciągu roku $[2,3]$.

Głównymi trudnościami napotykanymi podczas leczenia szpiczaka jest destrukcja kości, niewydolność szpiku kostnego, a także niewydolność nerek, które wpływają negatywnie na jakość życia chorego. W dobie obecnego rozwoju medycyny, chemioterapia i modyfikowane schematy leczenia znacznie przedłużają życie osób chorych na szpiczaka plazmocytowego, jednak w całości nie są w stanie przywrócić sprawności funkcjonowania osoby przed chorobą. To właśnie niesprawność jest zaburzeniem, które chorzy często zgłaszają personelowi medycznemu [2].

Szpiczak mnogi w wyniku patologicznych procesów zachodzących w szpiku kostnym, daje wiele specyficznych powikłań. Patogeneza objawów jest wieloczynni- 
kowa, gdyż intensywne leczenie przeciwnowotworowe, a nierzadko starszy wiek pacjenta mogą stanowić o trudnościach w prowadzeniu leczenia chorego. Występujące dolegliwości często prowadzą do obniżenia sprawności pacjenta. Głównym problemem zgłaszanym przez pacjentów chorujących na MM jest obniżenie sprawności fizycznej. Jest to spowodowane przez często pojawiające się patologiczne złamania odwapnionego kośćca czy przewlekły ból kostny, wynikający z nieprawidłowych procesów zachodzących w szpiku kostnym. Zmiany te w sposób istotny utrudniająl lub uniemożliwiają poruszanie się oraz wykonywanie czynności dnia codziennego. W opiece nad pacjentem ze szpiczakiem, ważna jest ocena funkcjonowania w zakresie sprawności fizycznej i samoobsługowej, może to zapobiec niepożądanym powikłaniom i upadkom $[4,5,6,7]$.

\section{Cel pracy}

Celem pracy było poznanie odczuć pacjentów co do własnej sprawności fizycznej w przebiegu choroby przewlekłej - szpiczaka mnogiego.

\section{Materiał i metody}

Grupę badanych stanowiło 100 pacjentów oddziałów hematologii leczonych zarówno stacjonarnie, jak i w trybie dziennego pobytu, w tym 47 kobiet i 53 mężczyzn. Spośród badanych 65 osób to pacjencioddziałustacjonarnego hospitalizowanipowyżej3dni,a35ankietowanych byłoleczonych $w$ ramach pobytu dziennego.

Zastosowanym narzędziem badawczym był walidowany kwestionariusz skali EORTC QLQ-30 wraz z modułem dotyczącym szpiczaka mnogiego QLQ-20, skala AIS oraz kwestionariusz autorski. Kwestionariusz EORTC QLQ-30 składa się z pięciu części, odnoszących się do funkcjonowania fizycznego, emocjonalnego, społecznego, pełnienia ról społecznych, pamięci i koncentracji. Dodatkowo włączone jest kilka pomniejszych skal oceniających objawy chorobowe tj.: zmęczenie, nudności i wymioty, ból, utrata apetytu, duszność, bezsenność, zaparcia, biegunka. Moduł QLQ-20 uzupetnia skalę o pytania specyficzne dla szpiczaka mnogiego [8]. Skala AIS składa się z ośmiu stwierdzeń opisujących negatywne konsekwencje złego stanu zdrowia. Stwierdzenia te sprowadzają się do uznania ograniczeń narzuconych przez chorobę, braku niezależności i samowystarczalności, obniżonego poczucia własnej wartości. Służy do pomiaru stopnia akceptacji choroby. Im większa akceptacja choroby tym mniejsze poczucie dyskomfortu psychicznego i lepsze przystosowanie do zaistniałej sytuacji. Suma wszystkich punktów jest ogólną miarą akceptacji choroby, jej zakres zawiera 8-40 punktów. Niski wynik oznacza brak akceptacji własnej choroby i przystosowania, natomiast wysoki wynik świadczy o braku negatywnych emocji związanych z chorobą [9]. Ankieta była anonimowa, a udział w niej dobrowolny. Pacjentów zapoznano z formą oraz metodą wypełniania ankiety i poinformowano o celu przeprowadzonych badań. Analiza statystyczna wykonana została w programie komputerowym Statistica. Do obliczeń użyto testów: chi-kwadrat, Kruskala-Wallisa oraz współczynnika korelacji rang Spearmana.

\section{Wyniki}

Respondenci najczęściej oceniali ogólny stan zdrowia w czasie ubiegłego tygodnia na poziomie 3-5, w skali 1-7. Interpretacja wyników subiektywnej oceny stanu zdrowia wskazuje, że większość ankietowanych swój stan zdrowia oceniła jako średni.

Tabela 1. Samoocena ogólnego stanu zdrowia ankietowanych \begin{tabular}{|c|c|c|c|c|c|c|c|c|} 
Bardzo zły & 1 & 2 & 3 & 4 & 5 & 6 & 7 & Doskonały \\
$2 \%$ & $5 \%$ & $25 \%$ & $22 \%$ & $26 \%$ & $19 \%$ & $1 \%$
\end{tabular}

Natomiast jakość swojego życia chorzy oceniali nieco lepiej niż ogólną ocenę stanu zdrowia. Mieściła się ona w przedziale 4-6, w skali 1-7. Otrzymane wynik wskazują na odczuwanie dobrej jakości życia.

Tabela 2. Samoocena jakości swojego życia \begin{tabular}{|c|c|c|c|c|c|c|c|c|} 
Bardzo zły & 1 & 2 & 3 & 4 & 5 & 6 & 7 & Doskonały \\
\hline $3 \%$ & $6 \%$ & $17 \%$ & $24 \%$ & $27 \%$ & $19 \%$ & $4 \%$ &
\end{tabular}

Otrzymane wyniki skali AIS wskazują, że 2\% ankietowanych uzyskało wynik w zakresie 0-10 pkt, 23\% 10-20 pkt. Niemal połowa ankietowanych (46\%) osiągnęło wynik w przedziale 20-35 pkt., a 29\% respondentów 30-40 pkt. Otrzymane wyniki wskazują, że większość ankietowanych (75\%) deklaruje niskie poczucie dyskomfortu psychicznego i dobre przystosowanie do zaistniałej sytuacji chorobowej. Zaobserwowano, że przystosowanie do choroby maleje wraz ze wzrostem wieku pacjentów.

Sprawność fizyczną pacjentów i trudności związane z wykonywaniem czynności dnia codziennego badano, pytająco trudności związanez wykonywaniem podstawowych czynności samoobsługowych i poruszaniem się. W przypadku grupy badanej dla większości osób długi spacer sprawiał większe trudności niż spacer krótki. Przy wykonywaniu ciężkich czynności aż 36\% osób miało trudności o największym nasileniu (bardzo nasilone trudności), 21\% o znacznym, a 31\% wskazywało na to, że mają częściowe trudności (trochę nasilone trudności). Uzyskane wyniki wskazują na utrudnioną sprawności i samodzielność tych chorych. 
Tabela 3. Męczliwość podczas długiego i krótkiego spaceru oraz kłopoty przy wykonywaniu męczących czynności

\begin{tabular}{|c|c|c|c|c|}
\hline Przedmiot obserwacji & Wcale & Trochę & Znacznie & Bardzo \\
\hline $\begin{array}{l}\text { Kłopoty przy } \\
\text { wykonywaniu męczących } \\
\text { czynności (np. przy } \\
\text { dźwiganiu ciężkiej torby } \\
\text { z zakupami) }\end{array}$ & $12 \%$ & $31 \%$ & $21 \%$ & $36 \%$ \\
\hline Długi spacer jest męczący & $19 \%$ & $28 \%$ & $32 \%$ & $21 \%$ \\
\hline Krótki spacer jest męczący & $53 \%$ & $32 \%$ & $4 \%$ & $11 \%$ \\
\hline
\end{tabular}

Zdecydowana większość respondentów (75\%) nie wymaga pomocy przy jedzeniu, ubieraniu się, myciu, korzystaniu z toalety, zaś $12 \%$ deklaruje, że wymaga niewielkiej pomocy, 8\% znacznej, a 5\% bardzo dużej. Znaczna część osób zmuszona jest by w ciągu dnia leżeć lub siedzieć niemal połowa ankietowanych (47\%) wykazała częściową konieczność (trochę), 19\% znacznie, 15\% bardzo. Ankietowani pytani o potrzebę odpoczynku w ciągu dnia najczęściej wskazywali oni na jej średnie nasilenie (trochę) $44 \%, 32 \%$ odczuwało znaczną potrzebę, $12 \%$ odczuwało duże jej nasilenie (bardzo), a 12\% nie deklarowało w ogóle takiej potrzeby (wcale).

Tabela 4. Pomoc w czynnościach dnia codziennego i konieczność odpoczynku w trakcie dnia

\begin{tabular}{|c|c|c|c|c|}
\hline Przedmiot obserwacji & Wcale & Trochę & Znacznie & Bardzo \\
\hline $\begin{array}{l}\text { Konieczna pomoc przy } \\
\text { jedzeniu, ubieraniu się, } \\
\text { myciu, korzystaniu } \\
\text { z toalety }\end{array}$ & $75 \%$ & $12 \%$ & $8 \%$ & $5 \%$ \\
\hline $\begin{array}{l}\text { Konieczność pozostawania } \\
\text { w łóżku lub fotelu w ciągu } \\
\text { dnia }\end{array}$ & $19 \%$ & $47 \%$ & $19 \%$ & $15 \%$ \\
\hline Potrzeba odpoczynku & $12 \%$ & $44 \%$ & $32 \%$ & $12 \%$ \\
\hline
\end{tabular}

Ankietowani byli pytani o odczuwane przez nich dolegliwości. Na podstawie zebranych wyników można stwierdzić, że większość pacjentów (59\%) nie odczuwa duszności, odpowiedź trochę wskazało $28 \%$ pacjentów. Spośród badanych 31\% wskazało na występowanie średnich dolegliwości bólowych (trochę), 30\% osób ma znaczne nasilenie, a 18\% skłaniało się ku odpowiedzi bardzo. Sumując odpowiedzi dotyczące występowania dolegliwości bólowych można stwierdzić, że ponad 3/4 badanych odczuwa ból o różnym nasileniu. Uczucie osłabienia jest najczęstszą dolegliwością chorobową występującą wśród ankietowanych, niewielkie nasilenie wykazuje $43 \%$ badanych, znaczne $30 \%$. Podobne wyniki ankietowani wykazali jeżeli chodzi o uczucie zmęczenia lub złego samopoczucia. Dolegliwości o niewielkim nasileniu zaobserwowano w skupianiu się (31\%) oraz w zapamiętywaniu (37\%). Lekkie uczucie spięcia towarzyszy 31\% ankietowanych.
Niewielkie trudności ze snem wykazuje 35\% badanych, znacznie utrudnione zasypianie ma 22\% osób. Większość ankietowanych (61\%) nie zgłasza dolegliwości ze strony przewodu pokarmowego (nadkwaśność, zgaga), niemal połowa (49\%) neguje ból i pieczenie oczu, zaś większość (69\%) zgłasza odczuwanie nieprzyjemnych doznań w dłoniach lub stopach. Uczucie pragnienia i suchości w jamie ustnej występuje u badanych w podobnym zakresie jest to niewielkie nasilenie dolegliwości (32\% - pragnienie i 35\% - uczucie suchości). Znaczne nasilenie obywdu wyżej wymienionych dolegliwości zgłaszało 30\% badanych.

Tabela 5. Odczuwane dolegliwości

\begin{tabular}{|l|c|c|c|c|}
\multicolumn{1}{|c|}{ Przedmiot obserwacji } & Wcale & Trochę & Znacznie & Bardzo \\
\hline Odczuwanie duszności & $59 \%$ & $28 \%$ & $9 \%$ & $4 \%$ \\
Odczuwanie bólu & $21 \%$ & $31 \%$ & $30 \%$ & $18 \%$ \\
Poczucie osłabienia & $21 \%$ & $43 \%$ & $30 \%$ & $6 \%$ \\
Odczuwanie zmęczenia & $22 \%$ & $37 \%$ & $36 \%$ & $5 \%$ \\
Złe samopoczucie & $37 \%$ & $29 \%$ & $18 \%$ & $16 \%$ \\
Trudności w skupianiu się & $55 \%$ & $31 \%$ & $8 \%$ & $6 \%$ \\
Trudności & $43 \%$ & $37 \%$ & $15 \%$ & $5 \%$ \\
w zapamiętywaniu & $52 \%$ & $31 \%$ & $14 \%$ & $3 \%$ \\
Uczucie spięcia & $35 \%$ & $35 \%$ & $22 \%$ & $8 \%$ \\
Trudności ze snem & $61 \%$ & $21 \%$ & $12 \%$ & $6 \%$ \\
Występowanie & $49 \%$ & $28 \%$ & $21 \%$ & $2 \%$ \\
nadkwaśności lub zgagi & $31 \%$ & $26 \%$ & $27 \%$ & $16 \%$ \\
Pieczenie i ból oczu & $33 \%$ & $32 \%$ & $30 \%$ & $5 \%$ \\
Odczuwanie mrowienia & $27 \%$ & $35 \%$ & $30 \%$ & $8 \%$ \\
w dłoniach lub stopach & & &
\end{tabular}

Bóle kości i pleców są najczęstszymi dolegliwościami wykazywanymi przez chorych na MM. Ból kości o niewielkim nasileniu występował u 43\% chorych, znacznym u 18\%, a dużym 17\%. Natomiast niewielki ból pleców wykazywało $37 \%$, znaczny $21 \%$, silny $17 \%$. Bóle biodra, ręki i ramienia szacowały się w podobnych przedziałach. Należy zwrócić uwagę, że lokalizacja bólu może świadczyć o miejscu ubytków kostnych i zmian chorobowych szpiczaka mnogiego.

Tabela 6. Odczuwanie bólu w zależności od jego lokalizacji, radzenie sobie $z$ bólem

\begin{tabular}{|l|c|c|c|c|}
\multicolumn{1}{|c|}{ Przedmiot obserwacji } & Wcale & Trochę & Znacznie & Bardzo \\
Odczuwanie bólu kości & $22 \%$ & $43 \%$ & $18 \%$ & $17 \%$ \\
Odczuwanie bólu pleców & $25 \%$ & $37 \%$ & $21 \%$ & $17 \%$ \\
$\begin{array}{l}\text { Odczuwanie bólu } \\
\text { w biodrze }\end{array}$ & $56 \%$ & $23 \%$ & $12 \%$ & $9 \%$ \\
$\begin{array}{l}\text { Odczuwanie bólu ręki lub } \\
\text { ramienia }\end{array}$ & $53 \%$ & $22 \%$ & $16 \%$ & $9 \%$ \\
$\begin{array}{l}\text { Odczuwanie bólu w klatce } \\
\text { piersiowej }\end{array}$ & $62 \%$ & $21 \%$ & $13 \%$ & $4 \%$ \\
$\begin{array}{l}\text { Ból przeszkadzał } \\
\text { w codziennych zajęciach } \\
\text { Odczuwanie wzrostu bólu } \\
\text { przy wykonywaniu } \\
\text { codziennych czynności }\end{array}$ & $30 \%$ & $22 \%$ & $27 \%$ & $21 \%$ \\
\hline
\end{tabular}


Na podstawie analizy statystycznej, przyjmując poziom istotności $p<0,05$ można stwierdzić, że występuje istotna statystycznie różnica $w$ trudnościach przy wykonywaniu męczących czynności dnia codziennego w zależności od wieku. Trudności przy wykonywaniu męczących czynności wzrastają wraz ze wzrostem wieku respondentów. Mężczyźni w większości męczą się trochę lub bardzo podczas długich spacerów, natomiast kobiety najczęściej znacznie męczą się podczas długich spacerów. Można również stwierdzić, że występuje istotna statystycznie różnica w zmęczeniu podczas krótkiego spaceru w zależności od wieku. Respondenci, którzy znacznie męczą się podczas krótkiego spaceru, charakteryzują się najwyższym wiekiem. Natomiast respondenci, którzy wskazali, że męczą się trochę lub wcale podczas krótkiego spaceru, są najmłodsi. Zmęczenie podczas długiego spaceru jest istotnie statystycznie zależne od płci.

Tabela 7. Arkusz wyników zależności dla zmiennych płeć i zmęczenie podczas długiego spaceru

\begin{tabular}{|l|c|c|c|c|c|}
\multicolumn{1}{r|}{ Płeć } & \multicolumn{5}{|c|}{ Długi space jest męczący } \\
& Trochę & Bardzo & Znacznie & Wcale & Razem \\
Mężczyzna & 17 & 21 & 4 & 11 & 53 \\
$\%$ & $32,08 \%$ & $39,62 \%$ & $7,55 \%$ & $20,75 \%$ & \\
Kobieta & 11 & 11 & 17 & 8 & 47 \\
$\%$ & $23,40 \%$ & $23,47 \%$ & $36,11 \%$ & $17,02 \%$ & \\
Ogół & 28 & 32 & 21 & 19 & 100
\end{tabular}

Na podstawie otrzymanych wyników można stwierdzić, że zmęczenie podczas krótkiego spaceru jest istotnie statystycznie zależne od płci. Mężczyźni w zdecydowanej większości w ogóle nie męczą się podczas krótkich spacerów, spośród kobiet $40 \%$ również nie odczuwa zmęczenia podczas krótkiego spaceru. Zaobserwowano istotną różnice w zakresie znacznego zmęczenia - duży odsetek kobiet (ponad 21\%) wskazało znaczne zmęczenie podczas krótkiego spaceru, wśród mężczyzn odsetek ten był nieporównywalnie mniejszy (1,89\%).

Tabela 8. Arkusz wyników zależności dla zmiennych płeć i zmęczenie podczas krótkiego spaceru

\begin{tabular}{|l|c|c|c|c|c|}
\multicolumn{1}{|c|}{ Płeć } & \multicolumn{4}{c|}{ Krótki spacer jest męczący } \\
\hline Mężczyzna & Wcale & Trochę & Znacznie & Bardzo & Razem \\
\hline$\%$ & $64,15 \%$ & $32,07 \%$ & 1 & 1 & 53 \\
\hline Kobieta & 19 & 15 & 10 & $1,89 \%$ & \\
\hline$\%$ & $40,43 \%$ & $31,91 \%$ & $21,28 \%$ & $6,38 \%$ & 47 \\
\hline Ogół & 53 & 32 & 11 & 4 & 100 \\
\hline
\end{tabular}

Ponadto zaobserwowano istotną statystycznie różnice w konieczności leżenia w tóżku lub siedzenia w fotelu w ciągu dnia w zależności od wieku. Respondenci, któ rzy charakteryzują się najniższym wiekiem, najczęściej deklarują brak konieczności leżenia w łóżku lub siedzenia w fotelu w ciągu dnia. Także w zakresie występowania dolegliwości bólowych występuje istotna statystycznie różnica. Odczuwana dokuczliwość bólu w codziennych zajęciach wskazuje na zależności występowania tego odczucia od wieku. Stwierdza się, że ból staje się coraz bardziej dokuczliwy wraz ze wzrostem wieku respondentów.

\section{Dyskusja}

Skumulowany wpływ choroby i czynników związanych z leczeniem wpływa na związaną ze zdrowiem jakość życia (HRQoL). U osób długotrwale leczonych jest słabo charakteryzowany. W badaniach E. Boland i wsp. dokonano szczegółowej oceny pacjentów, którzy byli poddani przeszczepowi komórek macierzystych i w wyniku postępującej choroby leczyli się co najmniej jednym cyklem. W badaniu wzięło udział 32 pacjentów, ze średnią 55 lat w diagnozowaniu i 60 lat w trakcie oceny. Po medianie 5,5 lat od diagnozy i trzech linii leczenia, ich sprawność fizyczna uległa istotnemu pogorszeniu $(p<0,001)$, co wiązało się z postępującą niepełnosprawnością $w$ pracy oraz obawą związaną z utratą niezależności. Zmęczenie i ból były przeważającymi objawami, wpływającymi negatywnie na funkcjonowanie fizyczne $(p<0,001)$. Ból był przeważnie neuropatyczny u $1 / 2$ pacjentów. Poziom interleukiny- $6 \mathrm{w}$ surowicy był dodatnio skorelowany z bólem $(p=0,03)$, bezsennością $(p=0,02)$ i utratą apetytu $(p=0,02)$, natomiast odwrotnie korelował $z$ funkcjonowaniem fizycznym $(p=0,03)$. Pomimo kontroli choroby i opieki wspomagającej intensywnie leczone osoby chore na szpiczaka mnogiego, pozostające w wywiadzie z przerzutami do szpiku kostnego, znacząco pogarszały HRQoL związane z obciążeniem objawowym [10].

W badaniach własnych wśród ankietowanych z krakowskiego szpitala chorzy zgłaszali większe dolegliwości bólowe. Występowały one u około $3 / 4$ chorych w różnym nasileniu. Bezsenność towarzyszyła znacznie $22 \%$ chorych natomiast brak apetytu występował znacznie u $17 \%$ pacjentów, trochę u 21\% chorych. Wiek korelował ze sprawnością fizyczną, chorzy starsi wykazywali większe deficyty w samoopiece.

W badaniu Molassiotis w sumie uczestniczyło $132 \mathrm{pa}$ cjentów ich QOL był umiarkowany, a główne problemy z zaburzeniami czynności fizycznych, emocjonalnych, społecznych i funkcji poznawczych były u pacjentów cierpiących na kilka objawów, w tym zmęczenie $(40,7 \%)$, ból $(35,9 \%)$, bezsenność $(32,3 \%)$, neuropatie obwodowe (28,3\%) i problemy z pamięcią (22,3\%). Około 40,8\% martwiło się zdrowiem w przyszłości [11]. 
Z kolei w przeprowadzonych badaniach własnych ankietowani zgłaszali objawy chorobowe o różnym nasileniu. Zmęczenie ogólnie wyraziło 78\%, ból 79\% (w tym znacznie $30 \%$, bardzo $18 \%$ ), trudności ze snem $65 \%$, problemy z pamięcią $57 \%$.

W badaniach Craike i współ. wykazują, że chorzy na szpiczaka mnogiego w podejmowaniu aktywności fizycznej w znacznej mierze napotykają bariery związane z objawami samej choroby (zmęczenie, ból kostny), ubocznymi efektami leczenia i obniżoną samooceną. Kobiety znacznie częściej niż mężczyźni uczestniczą w zróżnicowanych formach aktywności fizycznej, a także częściej korzystają z pomocy psychologicznej i socjalnej. Aktywność fizyczna wpływa na lepsze samopoczucie chorych na MM [12]. Również wyniki badań własnych wskazują na korelacje niepożądanych objawów choroby i leczenia ze zmniejszoną aktywnością fizyczną. Starszy wiek wpływał na większe trudności w poruszaniu (męczliwość podczas spacerów), lecz nie wpływał na ogólną subiektywną ocenę jakości życia tych pacjentów.

W efekcie dyskusji można wyciągnąc wniosek, że poziom niesprawności oraz dolegliwości chorobowych u chorych na szpiczaka mnogiego są wyższe u badanych pacjentów krakowskiego szpitala hematologicznego niż w wynikach przytaczanych badań. Badania ankietowe przedstawione w pracy na podstawie skali EORTC QOL stanowiły aktualny problem chorych na MM w 2017 r. Standardy leczenia są takie same, lecz można przypuszczać, że szpiczak mnogi w państwach zachodnich jest wcześniej rozpoznawalny i leczony niż w Polsce lub państwa te wykazują lepsze standardy opieki.

\section{Wnioski}

1. Chorzy na szpiczaka mnogiego mają znacznie obniżoną sprawność fizyczną. Głównymi deficytami są kłopoty przy wykonywaniu męczących czynności, ograniczenia w przechodzeniu dłuższych dystansów. Na obniżoną sprawność wpływa także szybka męczliwość, zmęczenie, złe samopoczucie.

2. Ponad $3 / 4$ ankietowanych chorych cierpi na dolegliwości bólowe o różnym stopniu nasilenia, które przeszkadzają im w wykonywaniu codziennych czynności.

3. Trudności przy wykonywaniu codziennych czynności wzrastają wraz z wiekiem respondentów. Z uzyskanych wyników skali AIS stwierdzono, że przystosowanie do choroby maleje wraz ze wzrostem wieku pacjentów.

4. Do najczęstszych powikłań choroby i ubocznych efektów leczenia należą: ból kościi pleców, osłabie- nie, odczuwanie mrowienia w dłoniach i stopach, uczucie suchości w jamie ustnej i pragnienie.

\section{Oświadczenia}

Oświadczenie dotyczące konfliktu interesów

Autorzy deklarują brak konfliktu interesów.

Źródła finansowania

Autorzy deklarują brak źródeł finansowania.

Piśmiennictwo

1. Iskierka-Jażdżewska E, Jamroziak K. Etiologia i patogeneza szpiczaka plazmocytowego. Hematologia, 2015; 6(3): 245-26.

2. Rome $S$, Jenkins B, Lilleby $K$ and the IMFNLB. Mobility and safety in the multiple myeloma survivor: Survivorship Care Plan of the International Myeloma Foundation Nurse Leadership Board. Clinical Journal of Oncology Nursing, 2011; 15(4): 41-52.

3. Dmoszyńska A. Postępy w rozpoznawaniu szpiczaka plazmocytowego oraz rekomendacje dotyczące leczenia. Po stępy Nauk Medycznych, 2011; 24(7): 592-600.

4. Jurszczyn A. i wsp. Niezbędne wymogi diagnostyczne i zalecenia terapeutyczne w szpiczaku plazmocytowym. Prz.Lek., 2013; 70(9): 744-753.

5. Usnarska-Zubkiewicz L, Bilińska M, Koszewicz M, Hołojda J, Pokryszko-Roczniak W, Babuśka-Roczniak M. Złamania patologiczne kości. Na Ratunek, 2013; (1): 22-25.

6. Zawiasa A, Nowicki M. Chora z ostrym uszkodzeniem nerek i białkomoczem nerczycowym. Med.Dypl., 2014; 23(9): 52-60.

7. Dragan A, Kuliczkowski K. Neuropatie obwodowe w przebiegu szpiczaka mnogiego i innych monoklonalnych paraproteinemii. Acta Haematologica Polonica, 2008; 39(1): 53-62.

8. Giesinger J, Kieffer J, Fayers P. et al. Replication and validation of higher order models demonstrated that a summary score for the EORTC QLQ-30 is robust. Journal of Clinical Epidemiology 2016; 69:79-88.

9. Zawisza K, Tobiasz-Adamczyk B, Nowak W. i wsp. Trafność i rzetelność kwestionariusza oceny jakości życia EORTC QLQ C30 oraz jego modułu dotyczącego pacjentek z nowotworami piersi (EORTC QLQ BR23). Ginekol. Pol. 2010; 81: 262-267.

10. Bolan E, Christine Eiser, Ezaydi Y. et al. Living with advanced but stable multiple myleoma: a study of the Symptom Burden and Cmulative Effects of Disease and Intensive (Hematopoietic Stem Cell Transplant-Based) Treatment on Health-Related Quality of Life. Journal of Pain and Symptom Managment 2013; 46(5): 671-680.

11. Molassiotis A, Wilson B, Blair S. et al. Unmet supportive care needs, psychological well being and quality of life in patients living with multiple myleoma and their partners. Psycho-Oncology 2011; 20: 88-97.

12. Craike M, Hose K, Courneya K. et al. Perceived benefits and barriers to exercise for recently treated patients with multiple myeloma: a qualitative study. BMC Cancer 2013, 13: 319.

Zaakceptowano do edycji: 20.08.19 Zaakceptowano do publikacji: 26.09.19

Adres do korespondencji:

Patrycja Zurzycka

ul. Kopernika 25

31-501 Kraków

tel: (12) 4214160

fax: (12) 4294872

e-mail: patrycja.zurzycka@uj.edu.pl 